\title{
The local turn and the framing of UNOCl's mandated activities by the UN
}

Article

Accepted Version

Gilder, A. ORCID: https://orcid.org/0000-0002-8861-1433 (2020) The local turn and the framing of UNOCl's mandated activities by the UN. Journal of International Peacekeeping, 23 (3-4). pp. 226-248. ISSN 1875-4112 doi:

https://doi.org/10.1163/18754112-20200007 Available at https://centaur.reading.ac.uk/101392/

It is advisable to refer to the publisher's version if you intend to cite from the work. See Guidance on citing.

To link to this article DOI: http://dx.doi.org/10.1163/18754112-20200007

Publisher: Brill

All outputs in CentAUR are protected by Intellectual Property Rights law, including copyright law. Copyright and IPR is retained by the creators or other copyright holders. Terms and conditions for use of this material are defined in the End User Agreement.

\section{www.reading.ac.uk/centaur}

\section{CentAUR}

Central Archive at the University of Reading 
Reading's research outputs online 
Author accepted manuscript - forthcoming in the Journal of International Peacekeeping (2020)

\title{
The local turn and the framing of UNOCI's mandated activities by the UN
}

\author{
Alexander Gilder \\ Department of Law and Criminology and Centre for International Security, Royal \\ Holloway, University of London, UK \\ Alexander.Gilder@rhul.ac.uk
}

\begin{abstract}
This article engages specifically with the local turn in UN peace operations by looking at local engagement and empowerment in the UN Operation in Côte d'Ivoire. After the closure of a long-serving UN peace operation it is important to take stock of the activities pursued under the mandate and reflect on how the mission has contributed to peacekeeping practice. UN peace operations have increasingly undertaken peacebuilding activities at the local level with current literature emphasising the need to involve local actors in decision-making and reconciliation activities. In seeking to uncover how the UN understands the need to involve local actors, the mission activities of UNOCI are broken down into a number of themes looking at how the local are engaged, given agency and empowered, and also where the UN recognises specific vulnerabilities of persons. The article shows how the UN portrays its activities and where it has either expressly or impliedly sought to demonstrate a concern for the local in Côte d'Ivoire.
\end{abstract}

\section{Keywords}

Peacekeeping - Côte d'Ivoire - local turn - vulnerability - local engagement - empowerment

\section{$1 \quad$ Introduction}

In recent years there has been a deluge of literature advocating bottom-up local engagement, and ultimately ownership, to ensure the dividends of peacebuilding reach those affected by conflict. This is in contrast with the previously dominant promotion of the liberal peace as a

\footnotetext{
* Lecturer in Law at Royal Holloway, University of London.
} 
top-down hegemonic project from the global North. However, it is not always clear in mandates and UN reporting where the local have been engaged or given agency. For instance, there are not typically section headings in the Secretary-General's periodic reports on particular UN peace operations detailing where the mission has sought to engage the local. It can then appear to a casual reader that the UN does not have much of a concern for the local. Particularly for future peacekeeping practice, the UN needs to be aware of ways in which relationships with local actors can be nurtured and promoted.

This article breaks down the UN documentation and shows where the UN have in fact sought to engage the local and reported the activity. As a long-deployed UN peace operation, the United Nations Operation in Côte d'Ivoire (UNOCI) spanned several developments in UN peacekeeping across the so-called third generation of missions. Multidimensional operations with large peacebuilding components and protection of civilian mandates under Chapter VII became the norm during UNOCI's deployment. Other studies have examined, for instance, the effectiveness of UNOCI, the implications of the certification of the 2010 election results by the $\mathrm{UN}$, the interplay between the local and international actors in the Ivorian conflict, the legality of regime change in Côte d'Ivoire, and the continuing role of elites in the peacebuilding process. ${ }^{1}$ This study's contribution is a view on how the UN itself has framed its various activities in Côte d'Ivoire and specifically how the UN portrayed its peacebuilding activities in Secretary-General reporting and other UN documentation. The purpose is to shed light on how mission activities are reported by the UN and draw out trends that can inform the planning of future peacebuilding activities. Although examples are found of where the UN reports on locallevel engagement, empowerment and identification of vulnerabilities, whether local voices impact the decision-making of the UN is not regularly reported. It is suggested the UN can incentivise local actors to work closely with the mission by more clearly demonstrating how local voices can be impactful at the Secretariat and in the Security Council.

\footnotetext{
${ }^{1}$ Alex J. Bellamy and Paul D. Williams, 'Local Politics and International Partnerships: The UN Operation in Côte d'Ivoire (UNOCI)' in: Daniel Druckman and Paul F Diehl (eds), Peace Operation Success: A Comparative Analysis (Brill 2013) 55-84; Dorina A. Bekoe, 'The United Nations Operation in Côte d'Ivoire: How a Certified Election Still Turned Violent', International Peacekeeping 25, no.1 (2018): 128-153; Bruno Charbonneau, 'War and Peace in Côte d'Ivoire: Violence, Agency, and the Local/International Line' International Peacekeeping 19, no.4 (2012): 508-524; Sean Butler, 'Separating Protection from Politics: The UN Security Council, the 2011 Ivorian Political Crisis and the Legality of Regime Change' Journal of Conflict and Security Law 20(2) (2015): 251-276; Giulia Piccolino, 'Peacebuilding and statebuilding in post-2011 Côte D'Ivoire: A victor's peace?', African Affairs 117/468 (2018): 485-508; Giulia Piccolino, 'David against Goliath in Côte d'Ivoire? Laurent Gbagbo's war against global governance', African Affairs 111/442 (2012): $1-23$.
} 
By taking UNOCI as a case study the mission is discussed in relation to the local turn and uses UN public documentation from the mission's inception to its closure in 2017. First, a discussion of the local turn places this study within the current literature by outlining how the local has become an important consideration for the UN. Second, examples are given of where the local have been engaged, where they have been given agency and empowered, and where vulnerabilities have been identified. What the article does not do is aim to provide an expansive critique of the UN's approach to the local, although some thoughts are offered. Nor does the article give express views on how best to engage the local. Instead the article clarifies how the UN has portrayed its approach to engaging the local over the course of UNOCI's deployment to highlight various best practices and areas for improvement both in the activities themselves and the UN's reporting. By providing this perspective the article aims to assist future research in both the UN's relationship with Côte d'Ivoire and wider UN peacekeeping practice.

The case study is useful from a temporal point of view due to UNOCI's long period of deployment from 2004-2017. As will be discussed in the first section, the local turn has largely come to pass after the UN experiences in Kosovo and East Timor and the international community's endeavours in Iraq and Afghanistan. Although it must be said that the local turn has existed in academic literature for much longer. What can be seen in the case study below is a gradual shift of the mission toward a conscious effort to pursue local engagement in the second half of the mission following the 2010 elections. Initially deployed in 2004, the mission mandate did not include any express objectives to pursue local engagement. ${ }^{2}$ Instead the mandate focused on monitoring the ceasefire, assisting with the disarmament, the demobilisation, reintegration and repatriation programme agreed under the peace agreement, the protection of civilians, supporting humanitarian assistance and the peace process, investigating human rights violations, using radio to promote an understanding of the peace process, and assisting with restoring law and order. ${ }^{3}$ During the first half of its deployment, from 2004 to 2010, UNOCI was faced with a stalled peace process and a five-year delay to the holding of elections. During those first years of the mission the case study shows limited engagement of the local.

Elections were not held until October 2010 where the Independent Electoral Commission (IEC) declared that Laurent Gbagbo had lost and Alassane Ouattara had become the new president. The UN certified the result from the IEC but there were open questions as

\footnotetext{
${ }^{2}$ Bellamy and Williams 'Local Politics and International Partnerships', 60.

${ }^{3}$ UN Security Council, Resolution 1528 (27 February 2004) S/RES/1528.
} 
Author accepted manuscript - forthcoming in the Journal of International Peacekeeping (2020)

to the inclusivity of the elections with Bekoe arguing 'UNOCI undermined its own strategy with the overriding objective to hold the elections, even under sub-optimal conditions, as part of the exit strategy. ${ }^{4}$ In the years that followed Gbagbo's arrest, UNOCI began to draw down its presence in Côte d'Ivoire with ultimate withdrawal and closing of the mission in June 2017. In the years following the 2010 elections the mission became more concerned with addressing post-conflict threats within communities caused by land disputes and access to natural resources. ${ }^{5}$ In addition, UNOCI undertook a number of initiatives to support peace at the local level and national reconciliation and social cohesion became a mission priority. ${ }^{6}$ As the case study will show this change in emphasis provided space for UNOCI to engage and empower communities.

\section{The local turn}

\subsection{What is the local turn?}

Since the 1990s there has been a growing understanding that there must be an emphasis on local actors, communities, and civil society to pursue 'peace from below'. ${ }^{7}$ Much of the literature derives from a critique of the liberal peace and top-down hegemonic approaches where the international community sought to implement various universal goals such as human rights norms, the rule of law, and democracy. ${ }^{8}$ Proponents of the liberal peace argue that under a democratic government and with a market economy post-conflict states are able to have sustainable peace. This view has been reflected in UN documents such as the UN's 1992 Agenda for Peace where it is stated that ' $[\mathrm{t}]$ here is an obvious connection between democratic practices - such as the rule of law and transparency in decision-making - and the achievement of true peace and security in any new and stable political order. ${ }^{\prime 9}$ The UN will be discussed in

\footnotetext{
${ }^{4}$ Bekoe, 'How a Certified Election Still Turned Violent', 147.

${ }^{5}$ UN Security Council, 'Special report of the Secretary-General on the United Nations Operation in Côte d'Ivoire' (28 March 2013) S/2013/197, para 15.

${ }^{6}$ UN Security Council, 'Special report of the Secretary-General on the United Nations Operation in Côte d'Ivoire' (31 March 2016) S/2016/297, para 50.

${ }^{7}$ Hanna Leonardsson and Gustav Rudd, 'The 'local turn' in peacebuilding: a literature review of effective and emancipatory local peacebuilding'. Third World Quarterly 36, no. 5 (2015): 825-839, 826.

${ }^{8}$ Joanne Wallis, 'Is There Still a Place for Liberal Peacebuilding?' in Hybridity on the Ground in Peacebuilding and Development, ed. Joanne Wallis, Lia Kent, Miranda Forsyth, Sinclair Dinnen and Srinjoy Bose (Canberra: ANU Press, 2018), 83-98, 83.

${ }^{9}$ UN Secretary-General, 'An Agenda for Peace' (17 June 1992) A/47/277, para 59.
} 
more depth in the following section but it suffices to say here that the UN has and arguably continues to work on the assumption that adherence to the goals found in the UN Charter necessitate multiple facets of the liberal peace.

Wallis explains the liberal peace was 'based on the assumption that liberalism was inherently attractive and offered the most likely path to peace and prosperity. ${ }^{10}$ In this sense, it can be suggested that the liberal peace was seen to be a favourable path due to the prevailing international system which comprises norms of sovereignty, universal human rights, and peremptory norms against torture, aggression and more. In addition, it has been said liberal peacebuilding allows for the emancipation of people with only international organisations and sufficiently capable states able to undertake such state (re)building projects under the liberal conception. ${ }^{11}$ Therefore, only the organisations which form part of the prevailing international system, and states from the global North which constructed the system, are those able to action the liberal peace and convert states which have failed under non-liberal orders.

As a top-down intervention, liberal peacebuilding necessarily has a disconnect from local people and communities. Under liberal conceptions of peace, it is perceived that the imposition of democracy, the rule of law, and human rights will be problematic. ${ }^{12}$ A top-down intervention is aimed at changing the minds of local people in a way that they then wish to pursue various liberal agendas. Chandler outlines how this creates a hierarchy of understanding where the international community assume they have a superior perspective and local people must adopt what is being taught. ${ }^{13}$ Similarly, Mac Ginty suggests peacebuilding activities can reinforce the idea that expertise must come from the outside and that local people 'are passive victims and recipients who lack the agency to chart their own path unaided.' ${ }^{14}$

Critiques of liberal peace are largely based on the idea that it is external actors, such as international organisations and coalitions of states, who possess the role of peace maker, keeper, and broker. ${ }^{15}$ Therefore, local voices are disempowered and lack a role in the peace

\footnotetext{
${ }^{10}$ Wallis, 'Is There Still a Place for Liberal Peacebuilding?', 83.

${ }^{11}$ Roger Mac Ginty, 'Hybrid peace: The interaction between top-down and bottom-up peace', Security Dialogue 41, no.4 (2010): 391-412, 395.

${ }^{12}$ David Chandler, 'Resilience and the 'everyday': Beyond the paradox of 'liberal peace', Review of International Studies 41, no.1 (2015): 27-48, 28.

${ }^{13}$ Ibid. 28.

${ }^{14}$ Roger Mac Ginty, 'Everyday peace: Bottom-up and local agency in conflict-affected societies', Security Dialogue 45, no. 6 (2014): 548-564, 551.

${ }^{15}$ Roger Mac Ginty, 'Where is the local? Critical localism and peacebuilding', Third World Quarterly 36, no.5 (2015): 840-856, 845.
} 
process where the post-conflict reconstruction is being conducted by external actors. ${ }^{16}$ Where post-conflict reconstruction is being carried out in a top-down manner Autesserre has identified that tenuous casual chains are made by peacebuilders. For instance, an external actor can suggest that 'providing rape victims with sewing machines (or chickens, or the means to set up a beauty salon) will help these women gain financial independence, which will in turn give them greater political voice, and will thus help end sexual violence. ${ }^{17}$ The tenuous casual chains are based on assumptions lacking local knowledge, which could provide more effective interventions. It is from issues such as this from which the local turn has gained traction.

What the local turn does is bring to the forefront local perceptions of peace and how local people believe sustainable peace can be brought about in their communities. ${ }^{18}$ The local turn is a 'fundamental challenge' to how the West/global North thinks about peace. ${ }^{19}$ The local is difficult to define but is seen to be any individual or grouping of persons on the receiving end of peacebuilding activities, whether they be military or economic, where local voices are unlikely to be heard. ${ }^{20}$ For the purposes of this article, there are a broad range of local actors at the sub-national level whose voices need to be heard by the UN when decisions are made about peacekeeping and peacebuilding activities. Autesserre provides a useful definition that the local includes the individual, family, clan, district, province or ethnic group (where the ethnic group is not a national level one). ${ }^{21}$

The local turn is premised on the idea that there exists a wealth of detailed knowledge at the sub-national level which can be tapped into by external actors. The local are then a primary focus for peacebuilders and inform decision-making. Following the discourse, the local are part of an 'emancipatory peace built from below' that includes legitimate everyday activities. ${ }^{22}$ A detailed literature review from Leonardsson and Rudd charts the scholarship on the local turn show that the peace-making potential of the local has been increasingly

\footnotetext{
${ }^{16}$ Elisa Randazzo, 'The paradoxes of the 'everyday': scrutinising the local turn in peace building', Third World Quarterly 37, no.8 (2017): 1349-1368, 1358.

${ }^{17}$ Séverine Autesserre, 'International peacebuilding and local success: Assumptions and effectiveness', International Studies Review 19, no.1 (2017): 114-132, 120.

${ }^{18}$ Isabell Schierenbeck, 'Beyond the local turn divide: lessons learnt, relearnt and unlearnt', Third World Quarterly 36, no.5 (2015): 1023-1032, 1027.

${ }^{19}$ Roger Mac Ginty and Oliver P. Richmond, 'The Local Turn in Peacebuilding: a critical agenda for peace', Third World Quarterly 43, no. 5 (2013): 763-783, 772.

${ }^{20}$ Caroline Hughes, Joakim Öjendal, and Isabell Schierenbeck, 'The struggle versus the song - the local turn in peacebuilding: an introduction', Third World Quarterly 36, no.5 (2015): 816-824, 818.

${ }^{21}$ Autesserre, 'International peacebuilding and local success', 116.

${ }^{22}$ Giulia Piccolino, 'Local Peacebuilding in a Victor's Peace. Why Local Peace Fails Without National Reconciliation', International Peacekeeping 26, no.3 (2019): 354-379, 356.
} 
recognised since the $1990 \mathrm{~s} .{ }^{23}$ International organisations and states began to respond to the local turn discourse in the 2000s following UN experiments of administration in Kosovo and East Timor and poor results of liberal peace interventions in Iraq and Afghanistan. ${ }^{24}$ The concept of human security also gained traction in the 1990s and early 2000s recognising that the individual must be given intrinsic value and that where the individual's interests compete with that of the state the former should be given priority. ${ }^{25}$ The human security discourse has similarly suggested that local voices are used to determine what is crucially important to people in conflict and that people are empowered to 'avoid some risks and demand improvements in the system of protection. ${ }^{, 26}$ In a similar vein, Randazzo says the varying perspectives on the local turn have a common understanding that the local be given agency and engaged with to uncover realities and concerns that can result in improvements in the intervention undertaken by external actors. ${ }^{27}$

Schierenbeck explains the local can be 'navigation points' and can support policymakers and peacebuilders. ${ }^{28}$ However, the local turn is not only about providing support which better informs a liberal peacebuilding intervention. Instead, local turn scholarship has focused on ownership and whether local actors are given elements of control of the peacebuilding process. This is important because if local actors are included in, and given ownership of, peace-building, peace-making and peace-keeping then they are more likely to cooperate and perceive an intervention as legitimate. ${ }^{29}$ It is the idea of ownership that sets the local turn on a collision course with the liberal peace. ${ }^{30}$ Richmond explains that 'ownership indicates choice and flexibility over institutional formats. ${ }^{31}$ Ownership means there must be a debate in each post-conflict situation as to what constitutes the local and what ownership

\footnotetext{
${ }^{23}$ Leonardsson and Rudd, 'The 'local turn' in peacebuilding', 826; See for instance Adam Curle, 'New challenges for citizen peacemaking', Medicine and War 10, no.2 (1994): 96-105.

${ }^{24}$ Mac Ginty, 'Where is the local?', 845; See also Mac Ginty and Richmond, 'The Local Turn in Peacebuilding', 768.

${ }^{25}$ Mac Ginty, 'Where is the local?', 846; Christopher Daase, 'National, Societal', and 'Human Security': On the Transformation of Political Language', Historical Social Research 35, no.4 (2010): 22-37.

${ }^{26}$ Commission on Human Security, Human Security Now (New York: 2003) 12; A human security based assessment of MINUSCA has been carried out here, Alexander Gilder, 'Human security and the stabilization mandate of MINUSCA', International Peacekeeping (2020) (advance access): 1-32.

${ }^{27}$ Randazzo, 'The paradoxes of the 'everyday', 1355.

${ }^{28}$ Schierenbeck, 'Beyond the local turn divide', 1025

${ }^{29}$ See e.g. Jeni Whalan, 'The Local Legitimacy of Peacekeepers', Journal of Intervention and Statebuilding 11, no.3 (2017): 306-320, 313.

${ }^{30}$ Vesna Bojicic-Dzelilovic and Mary Martin, 'Wholly local? ownership as philosophy and practice in peacebuilding interventions', Peacebuilding 6, no.3 (2018): 218-232, 222.

${ }^{31}$ Oliver Richmond, 'Beyond Local Ownership in the Architecture of International Peacebuilding', Ethnopolitics 11, no.4 (2012): 354-375, 354.
} 
Author accepted manuscript - forthcoming in the Journal of International Peacekeeping (2020)

means, not being predetermined by the liberal peacebuilders launching an intervention. ${ }^{32} \mathrm{An}$ intervention implies a denial of local ownership in the short term but 'local ownership implies that actors choose what they own and how they own it, rather than taking possession of what is given to them.' Local ownership then necessitates external actors giving space for the local to be engaged and for a relationship to develop where they work in tandem with the international community on local priorities.

There are critiques of the local turn. It is not the purpose of this article to provide an exposé of the strengths and pitfalls of a focus on the local, but some examples of critiques will briefly be given here for context. For instance, 'the locals' are far from being a homogeneous and well-defined entity and there are multiple connections that link the different 'locals' with the global (and national). ${ }^{33}$ The local are linked to a 'web of clientelist networks' which means they are never purely local and tied to national discourses by persons with the necessary connections. ${ }^{34}$ Autesserre's definition given above will likely have a number of criticisms and others have said there is 'an unmistakeable tendency for vagueness about who or what constitutes 'local', ${ }^{35}$ There may also be situations where the local are given some form of ownership at a lower level but are not able to dictate the overall direction of the peacebuilding plan. ${ }^{36}$ This can result in empowered locals still remaining part of a liberal peacebuilding plan where token ownership is given with the aim of legitimising Western understandings of democracy and the rule of law. Lastly, the local have also been 'romanticised' where local approaches are seen to be 'more authentic, natural, and good than international ones. ${ }^{37}$ However, local actors are able to create frameworks and systems that result in impunity, injustice and other negative outcomes.

\subsection{The UN's understanding of the local turn}

The above section has outlined the local turn and its emergence as a critique of the liberal peace and alternative approach to peace-building, peace-making and peace-keeping. What was not

\footnotetext{
${ }^{32}$ Ibid. 355.

${ }^{33}$ Schierenbeck, 'Beyond the local turn divide', 1028.

${ }^{34}$ Piccolino, 'Local Peacebuilding in a Victor's Peace', 361, 374.

${ }^{35}$ Whalan, 'The Local Legitimacy of Peacekeepers', 307.

${ }^{36}$ Randazzo, 'The paradoxes of the 'everyday', 1353.

${ }^{37}$ Piccolino, 'Peacebuilding and statebuilding in post-2011 Côte D'Ivoire', 488; Sarah von Billerbeck, Whose Peace? Local Ownership and United Nations Peacekeeping. (Oxford: Oxford University

Press, 2016), 63-4.
} 
discussed is how one of the largest international organisations, which routinely undertakes many forms of intervention, perceives the local. Mac Ginty describes the 1992 Agenda for Peace as the 'seminal document in the development of modern peacebuilding' but states that it does not make use of the word 'local'. ${ }^{38}$ More recent initiatives and UN documentation do prioritise local engagement and ownership. Under the leadership of Secretary-General Kofi Annan, the UN recognised the need to 'build local capacities for conflict resolution' and that the UN's role is to support the creation of conditions under which the local population can achieve a sustainable peace. ${ }^{39}$ Later on in 2008 , with regards to civic engagement, the UN stated 'engagement is regarded as an important governance norm that can strengthen the decision-making arrangements of the state and produce outcomes that favour the poor and the disadvantaged. ${ }^{40}$ In this regard it can be seen that the UN appreciates the need to engage with a diverse range of actors, some of whom will constitute sections of the local, to achieve meaningful improvements. Specifically, with regards to UN peace operations, the High-Level Independent Panel on Peace Operations (HIPPO) recommended in 2015 that,

\begin{abstract}
'[e]ngagement must increasingly be regarded as core to mission success. By shifting from merely consulting with local people to actively including them in their work, missions are able to monitor and respond to how local people experience the impact of peace operations. That helps the mission to ensure that it does no harm. Ongoing community engagement also helps the mission to design better protection strategies to ensure the mission is more effective in improving the lives of the people it is deployed to serve and protect. ${ }^{41}$
\end{abstract}

Ownership has also, on occasion, been mentioned in the UN reporting on its peace operations. For instance in one 2015 report on the United Nations Multidimensional Integrated Stabilization Mission in the Central African Republic (MINUSCA) the Secretary-General welcomed efforts to contribute to local ownership. ${ }^{42}$ Similarly, states in the Security Council have supported the HIPPO recommendations by expressing support for people-centred approaches where local people affected by conflict are able to be engaged and have

\footnotetext{
${ }^{38}$ Mac Ginty, 'Where is the local?', 840.

${ }^{39}$ UN Security Council, 'No exit without strategy: Security Council decision-making and the closure or transition of United Nations peacekeeping operations' (20 April 2001) S/2001/394, paras 11-2. ${ }^{40}$ UN, 'People Matter Civic Engagement in Public Governance' (2008) ST/ESA/PAD/SER.E/108, 23.

${ }^{41}$ UN Security Council and UN General Assembly, 'Identical letters dated 17 June 2015 from the Secretary-General addressed to the President of the General Assembly and the President of the Security Council' (17 June 2015) A/70/95-S/2015/446, 14.

${ }^{42}$ UN Security Council, 'Report of the Secretary-General on the situation in the Central African Republic' (30 November 2015) S/2015/918, para 65.
} 
Author accepted manuscript - forthcoming in the Journal of International Peacekeeping (2020)

ownership. ${ }^{43}$ In a 2016 report on the United Nations Mission in South Sudan (UNMISS) the Secretary-General demonstrates an understanding that engagement at the national level is distinct from engagement at the local level and that local engagement can have 'positive societal implications'. ${ }^{44}$

As will be seen in the case study below, the UN does provide space for local engagement emphasising the need to address local priorities, promote national reconciliation, and ultimately build a sustainable peace. Ownership though is distinct from engagement and Billerbeck reports that the UN 'remain[s] silent on how to build ownership in practice. ${ }^{45}$ The UN also often conflates local ownership with national ownership. ${ }^{46}$ For instance, where various national civil society groups are given a voice in the peace process the UN will regard this as local contribution to national reconciliation. Bojicic-Dzelilovic and Martin discuss how the UN sees local ownership as engaging with national government elites, not grassroot level local actors. ${ }^{47}$ This may be because UN staff believe local actors are unable to achieve peace on their own and lack the skills to help implement complex reconstructive projects. ${ }^{48}$ Billerbeck argues the negative perceptions of the local within the UN is due to the primacy of the liberal peacebuilding agenda where the local is simply given token ownership of a UN-designed template. ${ }^{49}$ The UN-designed template is simply that, UN-designed where the local 'are not empowered to play a role in determining that vision.' ${ }^{50}$ Similarly, Richmond claims 'local ownership becomes watered down into participation in externalized rather than localized processes. ${ }^{51}$ Billerbeck's research shows that local actors feel many decisions which determine the overall shape of a UN peace operations are 'foregone conclusions' and the UN only pays

\footnotetext{
${ }^{43}$ See e.g. UN Security Council, $7711^{\text {th }}$ Meeting (10 June 2016) S/PV.7711, 50 as per Mr. Chutikul and 55 as per Mr. De Aguiar Patriota; UN Security Council, 7947 $7^{\text {th }}$ Meeting (23 May 2017) S/PV.7947, 13 as per Mr. Lambertini.

${ }^{44}$ UN Security Council, 'Special report of the Secretary-General on the review of the mandate of the United Nations Mission in South Sudan' (10 November 2016) S/2016/951, para 33.

${ }^{45}$ Sarah von Billerbeck, 'Local Ownership and UN Peacebuilding: Discourse Versus Operationalization', Global Governance 21 (2015): 299-315, 303.

${ }^{46}$ See e.g. UN, From Rhetoric to Practice: Operationalizing National Ownership in Post-Conflict Peacebuilding Workshop Report (1 June 2011) < https://www.un.org/peacebuilding/sites/www.un.org.peacebuilding/files/documents/national_ownersh ip_report.pdf>

${ }^{47}$ Bojicic-Dzelilovic and Martin, 'Wholly local?', 221.

${ }^{48}$ Autesserre, 'International peacebuilding and local success', 123; von Billerbeck, 'Local Ownership and UN Peacebuilding', 302.

${ }^{49}$ von Billerbeck, Whose Peace, 57.

${ }^{50}$ Ibid. 60.

${ }^{51}$ Richmond, 'Beyond Local Ownership', 362.
} 
Author accepted manuscript - forthcoming in the Journal of International Peacekeeping (2020)

'lip service' to local ideas. ${ }^{52}$ The below case study sheds some light on where local voices are absent in UN reporting which may indicate an absence of the local in decision-making.

This article agrees with Bojicic-Dzelilovic and Martin in that local agency and empowerment is critical but must be filtered down effectively from the strategic level to the tactical and operational levels. ${ }^{53}$ Therefore, a UN peace operation should engage the local to determine the full range of local needs and expectations. ${ }^{54}$ Ownership can also not be achieved without building local capacities by engaging and empowering the local. ${ }^{55}$ In this regard the case study on UNOCI in the following section explores how the UN has framed its activities in three areas. First, where the local have been given space to be engaged. Second, where the local have been given agency and empowered. Finally, where the UN has recognised vulnerabilities as a separate set of needs. It must be said that the case study does not purport to show the complete picture of how the UN interprets and operationalises local engagement, empowerment and ownership. Instead the case study gives a chronological outline of activities which can be associated with the local turn.

\section{The local turn in UNOCI}

\subsection{Engaging the local}

The local turn argues that external actors must be guided from the bottom-up, not only by topdown understandings of peacebuilding. Here engaging the local means providing space for local people to communicate what they deem to be crucially important for their security, building sustainable peace, and supporting post-conflict reconstruction.

Initial discussions at the start of the mission were between Forces armées nationales de Côte d'Ivoire (FANCI) and Forces nouvelles on ways to reduce checkpoints, and between the Special Representative of the Secretary-General (SRSG) and regional heads of state on kickstarting the peace process. ${ }^{56}$ Since elections were not possible in 2005 , consultations were held on who should become Prime Minister but the UN does not make it clear in their reporting

\footnotetext{
52 von Billerbeck, Whose Peace, 72.

${ }^{53}$ Bojicic-Dzelilovic and Martin, 'Wholly local?', 218.

${ }^{54}$ Richmond, 'Beyond Local Ownership', 363.

${ }^{55}$ Leonardsson and Rudd, 'The 'local turn' in peacebuilding', 830.

${ }^{56}$ UN Security Council, 'Second report of the Secretary-General on the United Nations Operation in Côte d'Ivoire' (27 August 2004) S/2004/697, para 33; UN Security Council, 'Third progress report of the Secretary-General on the United Nations Operation in Côte d'Ivoire' (9 December 2004) S/2004/962, para 10.
} 
who made up the Ivorian parties consulted. ${ }^{57}$ With regards to the needs of local people, the UN states that providing basic services and improved security conditions are essential. ${ }^{58}$ Similarly, it is stated that ' $[\mathrm{t}]$ he lack of security continues to affect negatively the living conditions of most of the population. ${ }^{59}$ However, no further details are forthcoming on whether these local needs were communicated from the local, whether they represent what services and security issues are most valued by local populations, and how the UN intends to action any issues raised by communities.

Early examples of where the mission does provide space for the local to communicate needs can be seen from 2006 onwards. First, in October 2006 a workshop was held in which the government, UNOCI, other UN actors, humanitarian organisations, donors, and civil society 'take stock of the key protection challenges and to agree on action to be taken. ${ }^{60}$ The inclusion of civil society groups could mean local organisations but could also be only national elites and unrepresentative of diverse views of the local, again the UN does not make an express distinction. Second, UNOCI established sub-offices in other Ivorian cities, undertook peace caravans which visited schools, and held town hall meetings. ${ }^{61}$ This type of engagement certainly provides space for communities to raise the issues most important to them with UNOCI but are isolated examples. Third, civil society are included in the technical assessments of UNOCI from 2007. Civil society did express concern over the lack of information on the Ouagadougou Accords in the countryside and UNOCI was informed that its own troops had failed to protect civilians who were under attack. ${ }^{62}$ This is despite the Ouagadougou Accords being described by Charbonneau as a 'local' peace accord ${ }^{63}$ However, the UN provides limited further examples of what local needs and views were communicated by civil society. In the 2010 technical assessment of the mission, community groups informed UNOCI that a lack of social services, water, health care, and education contributed to lost opportunities to enhance

\footnotetext{
${ }^{57}$ UN Security Council, 'Seventh progress report of the Secretary-General on the United Nations Operation in Côte d'Ivoire' (2 January 2006) S/2006/2, para 1.

${ }^{58}$ Ibid. para 55.

${ }^{59}$ UN Security Council, 'Twelfth progress report of the Secretary-General on the United Nations Operation in Côte d'Ivoire' (8 March 2007) S/2007/133, para 22.

${ }^{60}$ UN Security Council, 'Eleventh progress report of the Secretary-General on the United Nations Operation in Côte d'Ivoire' (4 December 2006) S/2006/939, para 41.

${ }^{61} \mathrm{~S} / 2007 / 133$, para 50; UN Security Council, 'Fourteenth progress report of the Secretary-General on the United Nations Operation in Côte d'Ivoire' (1 October 2007) S/2007/593, para 54.

${ }^{62}$ UN Security Council, 'Thirteenth progress report of the Secretary-General on the United Nations Operation in Côte d'Ivoire' (14 May 2007) S/2007/275, paras 28-30.

${ }^{63}$ Charbonneau, 'War and Peace in Côte d'Ivoire', 516.
} 
Author accepted manuscript - forthcoming in the Journal of International Peacekeeping (2020)

social cohesion. ${ }^{64}$ In response, UNOCI and the UN Country Team prepared a strategic framework to re-establish social services but was underfunded in that regard. ${ }^{65}$ Technical assessments of the mission can be used to engage the local where communities and civil society are included and prepare appropriate responses to the needs raised. That being said, in the first six years of the mission the UN did not frame its activities as prioritising local engagement and examples are found scattered in the documentation as opposed to existing under consistent headings in the periodic Secretary-General reports, for example.

Following the 2010 elections there were several initiatives which provided clearer opportunities to engage the local. Under the Ouattara presidency the mission was more capable of undertaking its own initiatives and supporting government programmes that provide space for local engagement whereas under Gbagbo the mission struggled to move around the country and access populations in need. In 2012 UNOCI sought to reinforce 'its field presence with a view to increasing its engagement at the local level. ${ }^{96}$ By increasing their presence in the field the mission would be able to intensify its engagement with communities and improve the effective delivery of mandated activities and programmes. ${ }^{67}$ It is suggested here that an increased field presence is a major step in the direction of allowing bottom-up action where the mission can receive valuable information from local populations and feed those concerns into the mission's activities and programmes. It was later reported that the increased presence would enhance the mission's ability to protect civilians and would allow for conflict prevention and mitigation. ${ }^{68}$ Importantly for engaging the local, the Secretary-General's Special Representative for UNOCI believed this presence would foster 'more proactive outreach to other key actors on the ground. ${ }^{69}$ In 2013 , the mission explained that there would be locallevel protection of civilian working groups, that cell phones would be distributed to allow rapid response to sexual violence, and a call centre would be reactivated 'so that the population can

\footnotetext{
${ }^{64}$ UN Security Council, 'Twenty-fourth progress report of the Secretary-General on the United Nations Operation in Côte d'Ivoire' (20 May 2010) S/2010/245, para 44.

${ }^{65}$ Ibid. para 45.

${ }^{66}$ UN Security Council, 'Special report of the Secretary-General on the United Nations Operation in Côte d'Ivoire' (29 March 2012) S/2012/186, para 60.

${ }^{67}$ Ibid. paras 59, 78.

${ }^{68}$ UN Security Council, 'Thirty-first progress report of the Secretary-General on the United Nations Operation in Côte d'Ivoire' (31 December 2012) S/2012/964, para 62; UN Security Council, $6902^{\text {nd }}$ Meeting (17 January 2013) S/PV.6902, 4 as per Mr. Koenders.

${ }^{69}$ S/PV.6902, 4 as per Mr. Koenders.
} 
share its protection concerns with the Mission. ${ }^{70}$ The information collected would then be relayed to relevant bodies to be actioned upon and help identify areas of concern. ${ }^{71}$

Following the 2010 elections the documentation shows a manifest concern for understanding local-level issues. UNOCI proactively sought information by engaging with the local populations and put in place mechanisms which allows for communities to inform the mission of security concerns and other priority needs. Specifically for achieving the mission's protection of civilians mandate UNOCI supported awareness-raising and early warning committees. ${ }^{72}$ By working with communities on establishing the committees UNOCI was able to improve its working relationship with local authorities and more closely monitor security developments at a local level 'to help prevent conflict. ${ }^{73}$ What can be seen from the range of examples in this section is that it was not made evident by the UN in their framing of the discussion on UNOCI that the mission was concerned with hearing local-level issues from the beginning of the mandate. Instead the mission evolved and once the priorities shifted to supporting national reconciliation under the Ouattara government UNOCI was able to establish methods of engaging the local. However, Piccolino reports that government initiatives to improve community-level dialogue and cohesion have mixed results with the government's Commission Dialogue, Vérité et Reconciliation (CDVR) regarded as a failure by the population. ${ }^{74}$

\subsection{Empowering and giving agency to the local}

It is one thing to engage the local and seek their views but it is another to actively support the empowerment of the local to increasingly have agency, to have a voice that can be heard, and to become active participants in post-conflict reconstruction and national reconciliation efforts, which can ultimately lead to ownership of their security. The early stages of UNOCI's mandate focused on the warring parties and priorities were the commencement of the disarmament, demobilization, rehabilitation, and reintegration (DDRR) process, restoration of state authority, and, as will be discussed below, the facilitation of credible elections. ${ }^{75}$ There is no initial

\footnotetext{
${ }^{70} \mathrm{~S} / 2013 / 197$, para 35.

${ }^{71}$ Ibid.

${ }^{72}$ UN Security Council, 'Thirty-fifth progress report of the Secretary-General on the United Nations Operation in Côte d'Ivoire' (12 December 2014) S/2014/892 para 15.

${ }^{73}$ Ibid.

${ }^{74}$ Piccolino, 'Peacebuilding and statebuilding in post-2011 Côte D'Ivoire', 500.

${ }^{75}$ S/2004/697, para 61.
} 
Author accepted manuscript - forthcoming in the Journal of International Peacekeeping (2020)

mention of UN supported local-level peace initiatives, UN encouragement of local involvement in the peace process or national reconciliation until later in the course of the mission. Instead of promoting national reconciliation from the bottom-up, UNOCI sought to reintegrate former combatants and also disseminated information through the mission's radio station, UNOCI FM. ${ }^{76}$ UNOCI FM formed collaborations with local radio stations, broadcasted information on the electoral process and in one case the mission provided equipment to a community radio station. ${ }^{77}$ Three years after deployment the UN recognised that disputes at the community-level are problematic and cause displacement. ${ }^{78}$ In the years that followed the mission did begin to undertake hands-on local peacebuilding activities with a view to empowering the local.

In 2006, the aforementioned UNOCI Gender Unit trained women candidates for the elections alongside civil society but the empowerment of women was not a key concern of the mission until closer to the elections. ${ }^{79}$ In 2007 civil society requested that the UN do more to empower women and in the following year UNOCI assisted the government in preparing an action plan on the participation of women in the peace process. ${ }^{80}$ UNOCI further provided support for civil society in promoting the participation of women as both candidates and voters. ${ }^{81}$ Shortly after these activities the Security Council mandated UNOCI to remove obstacles and challenges to women's full participation and involvement in public life. ${ }^{82}$

The overriding focus of the discourse put forward by the UN and the Security Council's mandates were to provide support for elections in general, not only to empower women to take part. In 2005 UNOCI's mandate was altered to include support for free, open and fair elections by providing assistance to the government and Independent Electoral Commission where necessary. ${ }^{83}$ In 2007 it was specifically stated the mandate was renewed to provide support for

\footnotetext{
${ }^{76}$ UN Security Council, 'Seventh progress report of the Secretary-General on the United Nations Operation in Côte d'Ivoire' (3 January 2006) S/2005/604, para 12.

${ }^{77}$ UN Security Council, 'Fourth progress report of the Secretary-General on the United Nations Operation in Côte d'Ivoire' S/2005/186 (18 March 2005), para 56; UN Security Council, 'Sixth progress report of the Secretary-General on the United Nations Operation in Côte d'Ivoire' (26 September 2005) S/2005/398, paras 51-2

${ }^{78}$ UN Security Council, 'Report of the Secretary-General on children and armed conflict in Côte d'Ivoire' (30 August 2007) S/2007/515 para 3.

${ }^{79} \mathrm{UN}$ Security Council, 'Eighth report of the Secretary-General on the United Nations Operation in Côte d'Ivoire' (11 April 2006) S/2006/222, para 64.

${ }^{80}$ S/2007/275, para 29; UN Security Council, 'Fifteenth progress report of the Secretary-General on the United Nations Operation in Côte d'Ivoire' (2 January 2008) S/2008/1, para 56.

${ }^{81}$ UN Security Council, 'Seventeenth progress report of the Secretary-General on the United Nations Operation in Côte d'Ivoire' (10 July 2008) S/2008/451, para 53.

${ }^{82}$ UN Security Council, Resolution 1826 (29 July 2008) S/RES/1826 para 7; UN Security Council, Resolution 1880 (30 July 2009) S/RES/1880, para 9.

${ }^{83}$ UN Security Council, Resolution 1609 (24 June 2005) S/RES/1609 para 2 (q), (r), (s).
} 
the organisation of elections. ${ }^{84}$ The SRSG reported that much of UNOCI's attention was given to electoral support in 2008 with activities to further intensify in $2009 .{ }^{85}$ Briefings delivered on UNOCI to the Security Council from 2008-2010 were overwhelmingly focused on elections and little information on other issues is conveyed. ${ }^{86}$ UNOCI therefore very much became a one track mission and concerns of the local risked becoming lost.

The UN not only provided equipment and logistical support but the SRSG was also granted the role of certifying every stage of the results. ${ }^{87}$ As a result of this mandate, when the results of the elections were disputed between supporters of Gbagbo and the eventual winner President Ouattara, the UN was forced to carry out its certification role and declare a winner. ${ }^{88}$ The UN had previously been heavily criticised by a propaganda campaign in Côte d'Ivoire and by declaring Ouattara as the rightful President risked causing further divisions and entrenching the anti-UN sentiments held by certain groups. In opposition to the idea that the UN acted partially by involving itself in the political affairs of Côte d'Ivoire the UN has since been critical of the government's lack of action in pursing the prosecution of its own human rights abusers and the perceived targeting of forces loyal to Gbagbo. Criticism remains though with Bekoe arguing 'UNOCI appeared to prioritize the organization of elections over the establishment of a conducive environment for those elections to take place. ${ }^{89}$ Particularly important for how the UN frames its activity is that a former member of the UN's Group of Experts on Côte d'Ivoire reported UNOCI had wanted passages of the Group's MarchSeptember 2010 report rewritten in an effort to play down any risk to the elections. ${ }^{90}$ The release of the report was delayed until the following year in an effort to 'suppress information of the increasingly deteriorating situation in Côte d'Ivoire. ${ }^{91}$ The situation with the Group of Expert's report shows the UN can exert pressure to ensure positive reporting of a mission in critical periods of time. Such pressure may mean UN reporting is not an accurate depiction of the mission's activities. It is important though to note how material relating to the elections

\footnotetext{
${ }^{84}$ UN Security Council, Resolution 1765 (16 July 2007) S/RES/1765 para 1.

${ }^{85}$ UN Security Council, 6113 ${ }^{\text {th }}$ Meeting (28 April 2009) S/PV.6113, 2 as per Mr. Choi; UN Security Council, 'Twenty-first progress report of the Secretary-General on the United Nations Operation in Côte d'Ivoire' (7 July 2009) S/2009/344, para 21.

${ }^{86}$ See e.g. UN Security Council, $6168^{\text {th }}$ Meeting (23 July 2009) S/PV.6168; UN Security Council, $6263^{\text {rd }}$ Meeting (21 January 2010) S/PV.6263; UN Security Council, 6284 ${ }^{\text {th }}$ Meeting (17 March 2010) S/PV.6284. ${ }^{87}$ S/RES/1880, para 7.

${ }^{88}$ UN Security Council, 'Twenty-seventh progress report of the Secretary-General on the United Nations Operation in Côte d'Ivoire' (30 March 2011) S/2011/211, paras 16, 21.

${ }^{89}$ Bekoe, 'How a Certified Election Still Turned Violent', 146.

${ }^{90}$ Ibid. 146.

${ }^{91}$ Ibid. 146.
} 
Author accepted manuscript - forthcoming in the Journal of International Peacekeeping (2020)

may be skewed by the UN in favour of portraying a fair and transparent process where the local has been engaged.

In the lead up to, and especially following the elections, UNOCI began local peace initiatives that could promote reconciliation. The mission carried out activities at the community-level to strengthen social cohesion, but no specific details are given. ${ }^{92}$ In addition civil society was encouraged to hold events promoting the peace process and UNOCI 'carried out grass-roots advocacy interventions' to promote peaceful resolution. ${ }^{93}$ The SecretaryGeneral supported the expansion of assistance for activities which promote social cohesion and national reconciliation. ${ }^{94}$ Promoting social cohesion and community activities which contribute to national reconciliation can encourage communities to take ownership of the peace process, identify security issues, and resolve them to the best of their abilities. However, UN reporting on these activities is brief and it is difficult to conclude whether the local was given any true ownership in the peace process.

Reconciliation at national and local levels through the involvement of all Ivorians including women and civil society was mandated for by the Security Council in both 2013 and 2014. ${ }^{95}$ The UN recognised that community level work was important because a) communities had been militarised by the former regime and were former security personnel had returned home with weapons after Gbagbo's arrest and b) violent clashes between communities that have access to a large number of weapons could lead to large-scale conflicts. ${ }^{96}$ To mitigate the risk of escalation UNOCI supported the creation of two types of committees. First, local security committees which coordinate security activities at the local level with the involvement of local prefects, law enforcement and other officials. ${ }^{97}$ Second, local early warning and sensitization committees were created and include local authorities, politicians, civil society and traditional leaders. ${ }^{98}$ As a result, it was later reported that the early warning committees

\footnotetext{
${ }^{92}$ UN Security Council, 'Women and peace and security: Report of the Secretary-General' (16 September 2009) S/2009/465, para 46; UN Security Council, 'Twenty-sixth progress report of the Secretary-General on the United Nations Operation in Côte d'Ivoire' (23 November 2010) S/2010/600, para 57.

${ }^{93}$ UN Security Council, 'Eighteenth progress report of the Secretary-General on the United Nations Operation in Côte d'Ivoire' (13 October 2008) S/2008/645, para 53; S/2008/1, para 46.

${ }^{94} \mathrm{~S} / 2010 / 245$, para 43.

${ }^{95}$ UN Security Council, Resolution 2112 (30 July 2013) S/RES/2112, para 14; UN Security Council, Resolution 2162 (25 June 2014) S/RES/2162, 2.

${ }^{96}$ UN Security Council, 'Twenty-eighth progress report of the Secretary-General on the United Nations Operation in Côte d'Ivoire' (24 June 2011) S/2011/387, paras 22, 34; S/2012/186, para 22.

${ }^{97}$ UN Security Council, 'Twenty-eighth progress report of the Secretary-General on the United Nations Operation in Côte d'Ivoire' (24 June 2011) S/2011/387 para 65; S/2012/506, para 34.

${ }^{98}$ Ibid. para 35.
} 
Author accepted manuscript - forthcoming in the Journal of International Peacekeeping (2020)

'have been instrumental in easing intercommunity tensions and violence' and by 2015 there had been a slight decrease in inter-communal conflict. ${ }^{99}$ These examples further demonstrate that following the 2010 elections there was an effort to show UNOCI as supporting the creation of space for local communities to be empowered and have a voice in the peace process.

\subsection{Assessing vulnerabilities}

Engagement and empowerment of the local must not only include the so-called 'typical subjects' encompassing national elites and traditional community leaders who may wish to pursue goals that contravene the needs of local communities. ${ }^{100}$ Instead, the external actors must engage and empower "atypical' local interlocutors including prominently women and youth as well as other traditionally marginalised categories, notably internally displaced population and minority groups. ${ }^{101}$ Richmond identifies that the local should include diversity and depth where women, young people, indigenous peoples, displaced groups, and other marginalised communities are involved as they may the ideologies and norms brought forward by the external actor. ${ }^{102}$

A trend visible in the UN reporting on UNOCI is the recognition of vulnerable groups who require additional protections or assistance to increase their participation in the reconciliation process. Côte d'Ivoire has seen rampant sexual violence against women and girls and the use of child soldiers, but the particular vulnerability and consequent specific protection of women and children was not included in the first mandate, Resolution 1528. In 2004, child soldiers are mentioned as they were used by Forces nouvelles but their vulnerability and specific needs are not assessed. However, the UN does on occasion recognise particular communities and populations as vulnerable. For instance, quick impact projects were used to support HIV/AIDS programmes in 'vulnerable communities'. ${ }^{103}$ Similarly, 'vulnerable populations' are recognised where suffering from lack of medicines, insufficient drinking water, food insecurity, and malnutrition. ${ }^{104}$

\footnotetext{
${ }^{99}$ UN Security Council, 'Thirty-second progress report of the Secretary-General on the United Nations Operation in Côte d'Ivoire' (26 June 2013) S/2013/377, para 43; UN Security Council, $7358^{\text {th }}$ Meeting (13 January 2015) S/PV.7358, 4 as per Ms. Mindaoudou.

${ }^{100}$ Piccolino, 'Local Peacebuilding in a Victor's Peace', 358.

${ }^{101}$ Bojicic-Dzelilovic and Martin, 'Wholly local?', 222.

${ }^{102}$ Richmond, 'Beyond Local Ownership', 364-5.

${ }^{103} \mathrm{~S} / 2004 / 962$, para 63.

${ }^{104}$ S/2005/186, para 61; S/2013/377, para 58 .
} 
The needs of women and children as particularly affected groups were mainstreamed into the mandate from 2005 onwards. UNOCI had a Gender Unit which worked on issues of vulnerability and on increasing women's participation in elections. ${ }^{105}$ Child protection first featured as a section of the mission's reporting in 2005 due to the fact the mission was given a child protection advisor to mainstream child protection and identify 'key vulnerabilities'. ${ }^{106}$ Under this heading of child protection UNOCI concluded an agreement with Forces nouvelles to stop the use of child soldiers which is reported as the first of its kind in a peace operation. ${ }^{107}$ The UN recognises that children are especially affected by conflict and their vulnerability increases where they are unable to access education, health care and nutrition. ${ }^{108}$ In 2007 , during the technical assessment of the mission, civil society groups asked the UN to pay close attention to the needs of women and children associated with the armed groups. ${ }^{109}$ The resulting mandate renewal included the protection of women and children including monitoring and reporting on the issue. ${ }^{110}$ In 2010 , the mandate specifically stated that women, children, the elderly, disabled persons and displaced person are members of vulnerable groups. ${ }^{111}$ The mission has recognised vulnerabilities which demonstrates concern for groups which may need additional support to be engaged and participate in reconciliation, but it not always clear what actions are taken in response to the identification.

To specifically respond to vulnerabilities and build future resilience UNOCI focused on assisting the vulnerable groups alongside the government by formulating plans of action. Some resilience building is left to the humanitarian community, such as where it was said humanitarian actors would assist the Ivorian authorities with enhancing access to education and employment for youth. ${ }^{112}$ UNOCI has also worked with the government to create a national action plan to combat sexual violence and supported the establishment of a national commission for war-affected children. ${ }^{113}$ Nevertheless, sexual and gender-based violence and human rights violations against children continued in the years that followed. ${ }^{114}$ Though by the

\footnotetext{
${ }^{105} \mathrm{~S} / 2005 / 398$, para 63.

$106 \mathrm{~S} / 2005 / 604$, para 52.

$107 \mathrm{~S} / 2006 / 222$, para 58.

${ }^{108}$ UN Security Council, 'Report of the Secretary-General on children and armed conflict in Côte d'Ivoire' (25 October 2006) S/2006/835, para 4.

$109 \mathrm{~S} / 2007 / 275$, para 29.

${ }^{110}$ UN Security Council, Resolution 1795 (15 January 2008) S/RES/1795, para 6.

${ }^{111}$ UN Security Council, Resolution 1933 (30 June 2010) S/RES/1933, para 16(f).

${ }^{112} \mathrm{~S} / 2007 / 275$, para 76 .

${ }^{113}$ UN Security Council, 'Sixteenth progress report of the Secretary-General on the United Nations Operation in Côte d'Ivoire' (15 April 2008) S/2008/250 para 60; S/2008/645, para 48.

${ }^{114}$ UN Security Council, 'Twenty-second progress report of the Secretary-General on the United Nations Operation in Côte d'Ivoire' (29 September 2009) S/2009/495, paras 37, 41.
} 
Author accepted manuscript - forthcoming in the Journal of International Peacekeeping (2020)

time the mission was nearing closure UNOCI recorded the lowest number of violations against children between April 2016 and January 2017. ${ }^{115}$

The discourse put forward by the UN places strong emphasis on the participation of women. In 2015 the SRSG also reported that a National Council for Women had been launched to encourage the participation of women in decision-making and politics, however it is not reported what role UNOCI played in the creation of the council. ${ }^{116}$ The SRSG continued to note that more and more women were becoming involved in the public sphere and that women were becoming involved in social, economic, security and political issues. ${ }^{117}$ Although the number of women in the Ivorian National Assembly decreased in the 2016 elections the SRSG stressed that because a significant number of women ran for office that it was a positive step for the continued participation of women. ${ }^{118}$

\section{$4 \quad$ Mainstreaming the local into UN peace operations}

The local is a difficult subject to define. Rather than being narrow and focusing only on instances where the local have truly been given ownership of the peace process the case study above has given a broad range of examples where the discourse created by the UN reports that the local have been engaged, empowered or identified as particularly vulnerable. It is clear from the study that the UN does recognise the need to engage the local and groups are given agency and empowered to have a voice in the peace process, but this only became a more regular feature of mission reporting after the 2010 elections and during the Ouattara government. This finding partly aligns with Piccolino's research where,

'Ivorians interviewed generally agreed that peace and social cohesion at the local level are important and that social cohesion was only partly attained with the official end of the crisis in 2011. Tensions and mistrust persisted and affected the everyday experience of many Ivorians. ${ }^{119}$

Clearly, the situation improved at the end of the crisis in 2011 but deficiencies still existed with the UN unable to effectively resolve local issues even with a more cooperative host state government. It must not be brushed over though that the UN's prioritisation of the 2010

\footnotetext{
${ }^{115}$ UN Security Council, 'Final progress report of the Secretary-General on the United Nations Operation in Côte d'Ivoire' (31 January 2017) S/2017/89, para 40.

${ }^{116}$ UN Security Council, $7459^{\text {th }}$ Meeting (9 June 2015) S/PV.7459, 3 as per Ms. Mindaoudou

${ }^{117}$ UN Security Council, $7601^{\text {st }}$ Meeting (13 January 2016) S/PV.7601, 3 as per Ms. Mindaoudou; UN Security Council, 7880 ${ }^{\text {th }}$ Meeting (8 February 2017) S/PV.7880, 2 as per Ms. Mindaoudou.

${ }^{118}$ S/PV.7880, 2 as per Ms. Mindaoudou.

${ }^{119}$ Piccolino, 'Local Peacebuilding in a Victor's Peace', p.370.
} 
Author accepted manuscript - forthcoming in the Journal of International Peacekeeping (2020)

elections, and the surrounding examples given above, in the years leading up to Gbagbo's departure directly influenced a focus on national elites and not local peace.

What this study suggests is that part of the reason why the UN did not resolve the persistent tension and mistrust in Côte d'Ivoire is because examples of true ownership are absent from the UN reporting. As stated above, Richmond believes ownership indicates choice and flexibility over institutional formats. The UN reporting does not show how information garnered from the local has been used to inform decision-making. For instance, it is discussed how the mission sought to improve its field presence to intensify engagement and improve dividends for the local population. However, the UN does not provide any information in its reporting on whether the local population have been given agency to decide the direction of UN programmes or services being offered and tangible ownership of any local peace processes.

Civil society have also been mentioned on numerous occasions, but the UN does not explain who constitutes civil society making it impossible to determine whether the civil society groups represent the local or more traditional national elites. Overall, it is difficult to conclude whether more than lip service has been paid to local views when they have indeed been engaged with, but the reporting does show the UN wishes to portray a consistent concern for the local. By making more detailed and transparent reporting publicly available the UN can show local partners that their views and voices are being carried up to the Secretariat and Security Council's decision-making processes. The current situation where it is unclear whether consultations provide tangible results may lead to local actors to not prioritise working closely with the UN as they cannot impact the direction of a mission. An easily discernible commitment to local peace is needed in order for the UN to capitalise on the diverse array of local partners able to inform decision-making.

Some important points to note regarding engaging the local is that host state cooperation is needed to facilitate local-level peace initiatives that allow for the engagement and empowerment of the local. Initiatives like peace caravans that visit local schools and meetings across the country to meet with communities are unworkable where the mission's movements are limited by the host state forces. It was noted above how an increased field presence is a major step in the direction of allowing bottom-up action where the mission can receive valuable information from local populations and feed those concerns into the mission's activities and programmes but this is only possible with the cooperation of the authorities. Likewise, local authorities need to be invested in peacebuilding initiatives at the local level. For instance, the UN supported local authorities and law enforcement to be involved with local peace and early warning committees in Côte d'Ivoire. Without the engagement of local authorities, it would be 
difficult for solely the UN to implement the requests of the communities. In UNOCI there is also less attention given to vulnerability in the first few years of the mandate. The Security Council has become much more concerned with the protection of vulnerable persons, such as women and children, in the last decade and when UNOCI deployed in 2004 the Security Council's work on the issue was in its infancy.

What is needed going forward is much clearer UN reporting on its strategies and activities in relation to the local. Public UN documentation must show a commitment to the local but go further and provide interested parties with a fuller understanding of the local. The UN needs to adapt its mission reporting and mandating to show (1) activities which engage, give agency to, and empower the local and (2) how information from the local is being used and whether it affects decision-making at the operational or strategic-levels. However, other missions deployed today suffer from similar flaws found in UNOCI. ${ }^{120}$ For example, in the UN Multidimensional Integrated Stabilization Mission in Mali (MINUSMA) it is unclear in the reporting whether quick impact projects are constructed and carried out by the mission based on information from the local. ${ }^{121}$ Similarly in the UN Mission in South Sudan (UNMISS), mission reporting does not always state that mandate renewals have included local consultations. In 2015, the review of UNMISS' mandate did include a "cross-section" of stakeholders including displaced persons, women, youth, and civil society but in 2018 it is stated there were extensive consultations held with the government, diplomatic community and NGOs with no mention of whether local level consultations were held. ${ }^{122}$

If instead the UN consistently included a section in its periodic reports that covers engagement and empowerment of the local the UN would be able to show future local partners that their voices will be impactful by working the mission. The UN could also follow up on whether local engagement has provided dividends for the local in any way. The UN will also need to be conscious of its focus on elections. On the one hand, the Ouattara government provided space for many of the successful local peacebuilding activities that took place in the second half of the mission. But on the other hand, a preoccupation with ensuring elections take

\footnotetext{
${ }^{120}$ For examples in MINUSCA see Gilder, 'Human security and the stabilization mandate of MINUSCA', p.23. In MINUSMA

${ }^{121}$ See UN Security Council, 'Report of the Secretary-General on the situation in Mali' (2 January 2014) S/2014/1 para 44; UN Security Council, 'Report of the Secretary-General on the situation in Mali' (11 June 2015) S/2015/426 para 43; UN Security Council, 'Report of the Secretary-General on the Situation in Mali' (26 December 2017) S/2017/1105 para 62.

${ }^{122}$ UN Security Council, 'Special report of the Secretary-General on the review of the mandate of the United Nations Mission in South Sudan' (23 November 2015) S/2015/899 para 3; UN Security Council, 8192nd Meeting (27 February 2018) S/PV.8192 p.2 as per Ms. Keita.
} 
Author accepted manuscript - forthcoming in the Journal of International Peacekeeping (2020)

place, prioritised by the UN Security Council in its mandates, can distract from what is needed for local peace. To develop our understanding in this area future research could expound the relationship between the pursuit of elections alongside other peacebuilding activities and the dynamic that created between the national and the local. 